\title{
Teresa Sołdra-Gwiżdż*
}

Uniwersytet Opolski

\section{STOSUNKI ETNICZNE W BADANIACH INSTYTUTU ŚLAॄSKIEGO Z PERSPEKTYWY JEGO 80-LECIA}

\begin{abstract}
Artykuł przedstawia socjologiczny dyskurs o badaniach nad stosunkami etnicznymi i narodowymi prowadzony w Instytucie Śląskim od początków jego powstania, czyli od 1934 roku. Jego podstawowym celem było ukazanie znaczenia Śląska jako samoistnego przedmiotu badań i jako swoistego laboratorium społecznego oraz społecznych czynników rozwoju nauki. Ze względu na fakt, iż socjologowie omawiający stan badań w zakresie zagadnień etnicznych i narodowych w socjologii polskiej rzadko sięgają do dokonań instytutu, swoje rozważania rozpoczęłam od klasycznych studiów E. Szramka, J. Chałasińskiego, P. Rybickiego, S. Ossowskiego i S. Nowakowskiego, ukazując ewolucję problematyki badawczej i ujęć teoretycznych, które leżały u podłoża podejmowanych w nim przedsięwzięć. Perspektywa historyczna przyjęta w artykule umożliwiła mi przedstawienie znaczenia procesów zmiany społecznej dla odmiennej niż w czasach socjalizmu konceptualizacji problematyki etnicznej, przemian tożsamości, redefinicji jej i kulturowego uniwersum Ślązaków w kierunki uwidocznienia związków z Niemcami, a wśród młodego pokolenia powoli kształtującej się tożsamości europejskiej opartej na uniwersalnych wartościach.
\end{abstract}

Słowa kluczowe: stosunki etniczne, Instytut Śląski, przemiany tożsamości narodowej i etnicznej, instytucjonalne czynniki rozwoju nauki

\section{POWSTANIE ORGANIZACYJNYCH RAM INSTYTUTU ŚLĄSKIEGO W CELU ROZWOJU BADAŃ NAD PROBLEMATYKĄ NARODOWĄ I ETNICZNĄ. KLASYCZNE WĄTKI SOCJOLOGICZNEJ REFLEKSJI}

Etniczność i stosunki etniczne cieszą się nieustającą popularnością w rozważaniach socjologicznych. Szczególne miejsce zajmują w polskiej socjologii, która od początku swego powstania sytuowała problematykę narodu, w tym etniczności, niemal w centrum swego zainteresowania. Wystarczy wspomnieć rozważania nad rasą Ludwika Gumplowicza (Sto lat socjologii... 1995: 143-170), „organicyzm unarodowiony” Bolesława Limanowskiego (Sto lat socjologii... 1995: 182-193) czy też rozważania o narodzie Floriana Znanieckiego

* Adres do korespondencji: Teresa Sołdra-Gwiżdż, Uniwersytet Opolski, Instytut Socjologii, ul. Katowicka 89, 45-061 Opole, e-mail: tgwizdz@poczta.onet.pl. 
(Znaniecki 1990). O ich znaczeniu dla rozwoju polskiej myśli socjologicznej pisał już w okresie międzywojennym Jan Stanisław Bystroń, podkreślał je Józef Chałasiński, a także Jerzy Szacki (Bystroń 1917; Chałasiński 1948; Sto lat socjologii...1995).

Należy skonstatować, iż socjologowie omawiający stan badań nad zagadnieniami etnicznymi i narodowymi w socjologii polskiej rzadko sięgają do dokonań Instytutu Śląskiego, chociaż znaczenie Śląska jako samoistnego przedmiotu badań i jako swoistego laboratorium społecznego w tym zakresie jest oczywiste. Jedynie Nina Kraśko w swojej pracy o instytucjonalizacji socjologii w Polsce poświęciła nieco więcej uwagi śląskiej socjologii, wspominając Instytut Śląski jako placówkę powołaną w okresie międzywojennym w Katowicach z jego powojenną kontynuacją w Opolu oraz Śląski Instytut Naukowy powołany po II wojnie światowej ponownie w Katowicach (Kraśko 2010). Warto pamiętać, że studia empiryczne nad stosunkami etnicznymi na polskiej części Górnego Śląska, zrealizowane w okresie międzywojennym przez Józefa Chałasińskiego pod auspicjami Instytutu Śląskiego były jedynymi znaczącymi socjologicznymi dokonaniami badawczymi w tym zakresie, obok analizy struktury etnicznej Polesia prowadzonej przez Józefa Obrębskiego (Chałasiński 1935; Obrębski 1936). Nie należy pomijać również wkładu w socjologię stosunków etnicznych refleksji nad etnicznością Emila Szramka czy rozważań metodologicznych Pawła Rybickiego, a także krytycznej oceny dorobku śląskiej socjologii dokonanej przez rozpoczynającego wówczas swoją socjologiczną karierę Jana Szczepańskiego (Szramek 1934; Szczepański 1934; Szczepański 1935; Rybicki 1938). Na pamięć badaczy stosunków etnicznych zasługuje bez wattpienia wielkie przedsięwzięcie badawcze podjęte w 1933 roku przez Polski Instytut Socjologiczny w Poznaniu wraz z Fundacją Pokoju Carnegiego w Nowym Jorku (Carnegie Endowment for International Peace) dotyczące stosunków polsko-niemieckich na polskim Górnym Śląsku. W ramach tego ważnego i przygotowanego z rozmachem przedsięwzięcia badawczego ogłoszono dwa konkursy na pamiętniki Ślązaków, niestety cały ten cenny zbiór zaginął w czasie niemieckiej okupacji Poznania w latach 1939-1944. W wyniku ówczesnych badań powstało jednak kilka prac: wspomniana monografia J. Chałasińskiego, praca W. Rosa The Drama of Upper Silesia (mająca na celu zapoznanie zagranicznych czytelników z kwestią śląską), a także artykuł Jana Szczepańskiego Przejście z rodziny do szkoły w życiorysach młodzieży ślaskiej.

Powrócę jednak do genezy Instytutu Śląskiego, który powstał w 1934 roku w Katowicach i stanowił obok Instytutu Bałtyckiego drugą regionalną placówkę badawczą. Po odzyskaniu niepodległości sytuacja na polskiej części Śląska była trudna, brak było uniwersytetu czy jakiejkolwiek placówki, która organizacyjnie koordynowałaby badania naukowe. Wojewoda katowicki dr Michał Grażyński ze względu na upływającą w 1937 roku konwencją genewską oraz wiele społecznych problemów tego regionu, w tym sytuację etniczną oraz zagrożenia ze strony skrajnych kół niemieckich podjął starania o nawiązanie współpracy w zakresie badań nad Śląskiem z Uniwersytetem Jagiellońskim i Polską Akademią Umiejętności w Krakowie. Starania wsparły Śląska Rada Wojewódzka i Skarb Śląski, który wyasygnował znaczne środki finansowe na badania, a Instytut rozpoczął działalność w 1934 roku. Zaznaczę tylko, iż w 1937 roku rozpoczęto starania o utworzenie stacji naukowej Instytutu Śląskiego we Wrocławiu, chociaż w okresie międzywojennym do tego nie doszło. Kwestie etniczne 
postawiono w centrum zainteresowań badawczych instytutu, co zaowocowało ważnymi socjologicznymi pracami na ten temat, oprócz których powstawały także prace historyczne, geograficzne i językoznawcze.

W 1934 roku ukazała się praca Emila Szramka pt. Ślask jako problem socjologiczny. Próba analizy. Emil Szramek w niezwykle emocjonalny sposób, odmienny niż w innych pracach socjologicznych powstałych w latach trzydziestych minionego wieku, podją wiele kwestii związanych z kształtowaniem się stosunków etnicznych na Śląsku, a wśród nich problemy identyfikacji etnicznej i narodowej jednostek, relacji grupowych z Niemcami oraz stosunku Ślązaków do Polski i Polaków. Jako podstawowe procesy społeczne konstytuujące społeczeństwo śląskie wyróżnił migracje i antagonizm swój-obcy (sięgnął do studium Floriana Znanieckiego), uznając go za podstawowy wymiar stosunków grupowych na Śląsku (Znaniecki 1930/31). Warto podkreślić, że na polskiej części Śląska problem antagonizmu grupowego dotyczył nie tylko Niemców, ale także urzędników z Małopolski przyjeżdżających na Śląsk i wyrażał się w rozprzestrzenianiu postaw niechęci wobec nich, można nawet powiedzieć „śląskiej ksenofobii”. Ową nieufność Szramek próbował tłumaczyć obrazem Polaków w świadomości społecznej Ślązaków oraz brakiem wykształcenia się warstwy inteligencji wśród miejscowej ludności, co w jego przekonaniu stanowiło jeden z ważnych czynników konfliktogennych. Doceniając wagę teoretycznych rozważań nad zagadnieniami identyfikacji narodowej i etnicznej w poetycki sposób wskazał na efekty procesów społecznych związanych z kształtowaniem narodowej tożsamości jednostki, przyrównując osoby mieszkające na pograniczach do „kamieni granicznych, które z jednej strony noszą znamię polskie lub niemieckie” lub też do ,gruszy granicznych, które na obie strony rodzą”, a niezdecydowanie i zmienność w określaniu narodowej przynależności ukazał jako „trzciny chwiejące się na wietrze" (Szramek 1934: 18). Unaocznił także skomplikowane zagadnienia związane z konfliktem między znaczeniem Heimatu (małej ojczyzny) i Vaterlandu (dużej ojczyzny) a migracją do Rzeszy. Wykorzystując pojęcia zaczerpnięte z nauk ścisłych, „infiltracji, absorpcji i deworacji”, analizował społeczne procesy dotyczące kształtowania się stosunków etnicznych, których wyrazem były zjawiska czechizacji, germanizacji i polonizacji śląskiej ludności rodzimej.

Nieco inaczej kwestie antagonistycznych stosunków etnicznych na pograniczu podjął Józef Chałasiński, wskazując jako ich przyczynę ukryte irracjonalne siły sprawcze (mity, antropopsychizację rzeczywistości społecznej, symbole i stereotypy) prowadzące do konfliktowych relacji społecznych przenikających rodzinne i codzienne sąsiedzkie życie. Dzieje antagonizmu polsko-niemieckiego w osadzie „Kopalnia”, która była bezpośrednim przedmiotem studium Chałasińskiego determinowało wiele społecznych czynników. Antagonizm narodowy był ściśle związany z antagonizmem socjalnym jako antagonizmem dwu klasowych światów, izolowanych względem siebie, wynikającym ze stanowej struktury społecznej (Polacy to klasa robotnicza, a Niemcy Herrenvolk). Społeczne podłoże konfliktowych relacji społecznych stanowiły procesy germanizacyjne, konflikty o czysto lokalnym charakterze i konflikty osobiste wzmacniane również innymi cechami grupowymi: odmiennymi tradycjami, funkcjami ekonomicznymi, religią itp. Narastanie ich i przekazywanie w tradycji ustnej osady stworzyło tradycję antagonizmu narodowego, w którym trudno analitycznie rozgraniczyć poszczególne 
antagonizmy od siebie. System społeczny osady, mimo antagonistycznych stosunków społecznych, utrzymywał się jednak nie na skutek czysto fizycznej przemocy Niemców, ale dzięki społecznym postawom uległości całej osady względem rasy panów, doskonałości państwa niemieckiego, odczuwanej wyższości kultury niemieckiej (co potęgowało jej urok i wzbudzało przekonanie o niezwyciężonej potędze Niemiec), a także z powodu braku polskich elit mogących stać się naturalnymi przywódcami polskiej społeczności (Chałasiński 1935: 170). Ostra forma antagonizmu socjalno-narodowego wystapiła dopiero po I wojnie światowe, co wykorzystała propaganda plebiscytowa. Nowo wytworzona społeczna sytuacja umożliwiła zwycięstwo powstań i opowiedzenie się ludności za przynależnością do Polski. Ponowny ogląd osady dokonany z ,perspektywy długiego trwania” przez Tomasza Nawrockiego skłonił go do weryfikacji sądów dotyczących antagonizmu polsko-niemieckiego wyrażonych przez Chałasińskiego. Podał on w wątpliwość nie tylko siłę tego antagonizmu, ale także jego żywotność i zakres. Zdaniem Nawrockiego stosunki antagonistyczne istniały jedynie w części elit tej lokalnej społeczności dążących do pełnienia ról przywódczych i nie rozciągały się na całą społeczność. Zakwestionował również socjalne podłoże antagonizmu, uznając, iż gdyby był on „sprawą żywotną” dla tej społeczności nie zaniknąłby w społecznej świadomości (Nawrocki 2006). Odmienny obraz stosunków etnicznych między Polakami i Niemcami na Śląsku po 1989 roku wynika jednak z pracy Lecha Nijakowskiego, który przedstawia region śląski jako ,świat animozji narodowościowych”, wyrażających się przede wszystkim w walce o panowanie nad terytorium, jak to określa „domeny symbolicznej” (Nijakowski 2006).

Refleksję metodologiczną nad terenowymi badaniami socjograficznymi podjął z kolei Paweł Rybicki, ówczesny dyrektor Biblioteki Sejmu Śląskiego w Katowicach, zawierając ją w niewielkiej, ale znaczącej pracy pt. O socjograficznym badaniu Ślaska wydanej przez Instytut Śląski ${ }^{1}$. Sformułował metodologiczny postulat uwzględnienia „momentu historycznego" przy podejmowaniu wszelkich eksploracji Śląska. Posługując się kategorią pojęciową „stosunki ludnościowe”, a nie „stosunki międzygrupowe”, podkreślił sytuację społeczną wzajemnego izolacjonizmu grup etnicznych oraz uwypuklił odrębności życia społecznego, w którym dominowały dwa społeczne procesy: antagonizm i wzajemne przystosowanie.

\section{SOCJALISTYCZNA RZECZYWISTOŚĆ SPOŁECZNA. BADANIA NAD STOSUNKAMI ETNICZNYMI PO II WOJNIE ŚWIATOWEJ}

Wybuch wojny udaremnił kontynuację badań nad zjawiskami etnicznymi na Śląsku. Uwarunkowania makrostrukturalne: II wojna światowa, jej zakończenie przegrana Niemiec; zmiany granic Polski: utrata Kresów Wschodnich i związane z tym przesiedlenie dużych grup ludności, przyłączenie ziem zachodnich i północnych, w tym części dawnego niemieckiego Śląska, wysiedlenie Niemców, przekształcenia ustrojowe i przemiany ideologiczne wpłynęły na sposób uprawiana socjologii, podstawy teoretyczne i metodologiczne oraz problematyką badawczą. Wiele instytucji naukowych przedwojennej Polski wznowiło swoją działalność, w tym

1 Jak podaje Władysław Kwaśniewicz bez wiedzy i zgody autora ukazało się także tłumaczenie niemieckie. 
Instytut Śląski, który oficjalnie rozpoczął swoją pracę w Krakowie 22 stycznia 1945 roku, korzystając z pomocy pracowników Polskiej Akademii Umiejętności, a następnie pod koniec lutego powrócił do Katowic (Senft 1994: 33). Niewiele wiemy o badaniach socjologicznych na Śląsku w tamtych czasach. Problematyka badawcza określona na pierwszym posiedzeniu Komisji Socjograficznej Instytutu Śląskiego, która wznowiła prace na wiosnę 1945 roku pod kierunkiem doc. Pawła Rybickiego, obejmowała trzy nurty eksploracji: „1. przeobrażenia w świadomości narodowej ludu śląskiego, 2. ruchy migracyjne powojenne i konsekwencje społeczne, 3. zmiany społeczne w wyniku reform socjalno-gospodarczych" (Golachowski 1947). Stanisław Ossowski (wówczas profesor Uniwersytetu Łódzkiego) badania podjął już w sierpniu 1945 roku w położonej na Opolszczyźnie wsi Dobrzeń Wielki (noszącej w opracowaniu kryptonim Giełczyn (Ossowski 1984). Przybył tam wówczas ze swoim asystentem Janem Strzeleckim. Ponownie do niej powrócił (jako profesor Uniwersytetu Warszawskiego) w 1947 roku wraz z asystentami Stefanem Nowakowskim, Zygmuntem Pióro i Maciejem Czerwińskim oraz kilkoma starszymi studentami socjologii. Dało to początek w socjologii polskiej nurtowi „nowej socjologii Śląska” i nowemu socjologicznemu paradygmatowi badawczemu ziem zachodnich i północnych. Badania Ossowskiego w swej istocie odnoszą się do specyficznych relacji między więzią narodową i regionalną wyrażających się w dominacji więzi regionalnej stanowiącej podstawę uczestnictwa w regionalnej społeczności, (,zbiorowości swojaków”), która dla ludności śląskiej pełni funkcję „ojczyzny ideologicznej”, co było zaskoczeniem dla Ossowskiego, wcześniej bowiem sądził, że ojczyznę ideologiczną może stanowić tylko naród. Świadomość regionalną konstytuowały cztery nurty ideowe: katolicyzm, radykalizm społeczny, polskość i niemieckość. Analizując zjawisko zmienności narodowej oraz indyferentyzmu narodowego, skonstruował przymiotnikową koncepcję świadomości narodowej, której wyrazem było odkrycie rzeczownikowego (gatunkowego) i przymiotnikowego pojmowania przez dobrzeńskich Ślązaków pojęć „Polak” i „Niemiec”, która to koncepcja pozwoliła na ukazanie zróżnicowania intensywności związków z Polską w gromadzie (najsilniejsze wśród samodzielnych gospodarzy, najsłabsze wśród robotników). Unaocznienie znaczenia relacji międzygrupowych w małej lokalnej społeczności między Ślązakami i Niemcami oraz między Ślązakami a ludnością napływową wyznaczanych przez korelaty świadomościowe takie jak język, pochodzenie regionalne, odmienne losy historyczne i indywidualne doświadczenia określające pamięć przeszłości grupowej ukazało działanie socjologicznego ,,prawa tła” czyniącego Niemców bliższych Ślązakom niż Polakom, których nie rozumieli i których nazywali Ukraińcami. Takie świadomościowe usytuowanie Niemców w tamtych bezpośrednio powojennych czasach szokowało osadników i było znaczącym czynnikiem konfliktogennym.

Specyficzną formę socjologicznych badań terenowych stanowiło uczestnictwo członków Komisji Socjograficznej Instytutu Śląskiego w pracach wyjazdowych komisji kontrolujących weryfikację. Gromadzono materiały socjograficzne zbierane z wykorzystaniem kwestionariuszy ankiet, prowadzono badania archiwalne, zbierano materiały biograficzne za pomoca wywiadów (również teksty gwarowe), prowadzono badania ankietowe, których wyniki ujawniły zarówno początkowe konflikty i antagonizmy między obiema grupami ,przejawiające się m.in. w dążeniu do tworzenia odrębnych parafii śląskich i «repatrianckich» oraz przewalczenie 
ich i tworzenie się wspólnej więzi społecznej”2. Plany badań socjologicznych uwzględniały terytorialne rozszerzenie ich na Dolny Śląsk, co było związane z powstaniem oddziału instytutu we Wrocławiu, gdzie usytuowano dział socjograficzny (wrzesień 1945 roku), a następnie kolejnych ekspozytur placówki w Kłodzku i Wałbrzychu (Senft 1994). Brutalnie przerwany przez „stalinowską noc” socjologiczny dyskurs został wznowiony dopiero w drugiej połowie lat pięćdziesiątych po zaistnieniu określonych warunków instytucjonalnych. Losy Instytutu Śląskiego w okresie stalinizacji były podobne jak wielu innych instytucji naukowych, nastąpiło jego scalenie z Instytutem Zachodnim w Poznaniu. „Popaździernikowa odwilż” zaowocowała reaktywacją Instytutu Śląskiego, tym razem w Opolu, historycznej stolicy Górnego Śląska. W lutym 1957 roku odbyło się spotkanie, na którym podjęto decyzję o założeniu instytutu (założycielami było 70 wybitnych naukowców oraz działaczy społecznych z różnych ośrodków kraju) jako zarejestrowanego stowarzyszenia naukowego z Radą Naukową kierującą tą instytucją. Środowisko katowickie podjęło decyzję o powołaniu oddzielnego instytutu, a ponieważ dawnej nazwy używał instytut w Opolu, 13 marca 1957 roku uchwałą Wojewódzkiej Rady Narodowej powołano Śląski Instytut Naukowy w Katowicach, również jako stowarzyszenie naukowe wraz z Radą Naukową. Warto zaznaczyć zmianę funkcji założonych obu nowo powstałych instytutów w porównaniu z przedwojennym Instytutem Śląskim. Ich misją stało się samodzielne prowadzenie badań naukowych, a nie tylko działalność związana z ich organizacją, działalność wydawnicza czy popularyzatorska.

Wszystkie socjologiczne eksploracje w latach pięćdziesiątych i sześćdziesiątych ubiegłego wieku prowadzone na Opolszczyźnie kontynuowały problematykę, zapoczątkowaną przez Stanisława Ossowskiego i Stefana Nowakowskiego, adaptacji i integracji społecznej dużych grup ludności, które niekoniecznie z własnego wyboru musiały zamieszkać w obcej dla siebie przestrzeni fizycznej i kulturowej, tak jak ją nakreślili na mapie politycy i ,wiatr historii”. Każda powstająca $\mathrm{w}$ tym okresie praca stawiała sobie za cel ukazywanie stanu ich zaawansowania lub nawet formułowała tezy o ich zakończeniu (Świrski 1965; Kwaśniewski 1968; Oszewska 1969). Kontynuacja i rozwinięcie studiów Ossowskiego w Giełczynie, podjęte przez Stefana Nowakowskiego (z Anną Olszewską i Edwardem Ciupakiem), zaowocowały kilkoma pracami poświęconymi przeobrażeniom społecznym wsi i środowiska miejskiego również w zakresie stosunków etnicznych pod wpływem przemian ustrojowych (Nowakowski 1957). Przełamywanie czy zanikanie konfliktów i antagonizmów wynikających z kształtowania się wzajemnych negatywnych stereotypów w pierwszej fazie zetknięcia determinowały, w świetle tych studiów, czynniki narodowe, uświadomienie klasowe oraz wpływ wspólnej pracy. Antagonizm polsko-niemiecki w Giełczynie, zdaniem Nowakowskiego, nie miał charakteru narodowego, tak jak stało się to w ośrodkach przemysłowych Śląska, lecz miał charakter klasowy uwarunkowany

\footnotetext{
2 W ich wyniku podjęto następujące problemy badawcze: „Problematyka socjologiczna Śląska” (dr P. Rybicki); „Niemiecka lista narodowa na Górnym Śląsku” (dr Z. Izdebski); „Osadnictwo na Śląsku Opolskim” (dr H. Sukiennicki); „Zagadnienia zespalania się ludności miejscowej i napływowej na Śląsku Opolskim” (mgr S. Golachowski); „Weryfikacja ludności opolskiej” (dr Z. Izdebski); „Plan regionalny osadnictwa na Śląsku i jego realizacja” (mgr K. Krenzel); „Charakterystyka ludności opolskiej w świetle badań terenowych” (mgr S. Golachowski). Nie uznawano ich jednak za pełne badania socjologiczne, oceniając, iż mają one charakter badań wstępnych, nie są kompletne i nie są w pełni poprawne metodologicznie. Dzisiaj uznalibyśmy je za rodzaj zwiadu badawczego.
} 
jego systemem ekonomiczno-społecznym (Nowakowski 1960: 71). Inne, szczególnie ważne wątki badawcze, obrazujące zawansowanie procesów integracji, podejmowane przez Annę Olszewską i Kazimierza Żygulskiego to małżeństwa mieszane, prestiż zawodów na Śląsku oraz emigracja ludności rodzimej z województwa opolskiego do RFN (Żygulski 1958; Olszewska-Ładykowa, Żygulski 1959: 89-105; Żygulski 1959; Żygulski 1960; Żygulski 1964). Liczebność „małżeństw mieszanych” zawieranych od 1945 do 1954 roku nie była wysoka, jednakże autorzy sformułowali optymistyczną prognozę o postępujących procesach integracji i osłabieniu poczucia grupowych odrębności (Olszewska-Ładykowa, Żygulski 1959: 99; Żygulski 1959: 273). Trudno w tej chwili zrozumieć, jak godzono owe optymistyczne prognozy z innym zjawiskiem społecznym, czyli z masowymi wyjazdami ludności rodzimej do NRF i do NRD w ramach tak ,zwanej akcji łączenia rodzin” rozpoczętej w 1956 roku.

W latach siedemdziesiątych w wielu środowiskach uznano tezę polityczną o zakończonej integracji ziem zachodnich na skutek zawarcia traktatu między Polską a Republiką Federalną Niemiec o nienaruszalności granic. Po wycofaniu się przedstawicieli głównych ośrodków socjologicznych (Warszawy, Łodzi, Krakowa, Poznania) z prac Instytutu badania podjęli młodzi socjologowie, głównie wychowankowie Uniwersytetu Jagiellońskiego, a w późniejszym okresie Uniwersytetu im. Adama Mickiewicza w Poznaniu. Nawiązując do wątków badawczych Antoniny Kłoskowskiej, analizowano wyobrażenia i postawy etniczne wśród młodzieży szkół średnich miasta Opola oraz postawy patriotyczne uczniów (Kłoskowska 1960; Kłoskowska 1969; Pasierbiński 1997; Grygierczyk, Jałowiecki, Paszkiewicz i Woźniacki 1975). Wyniki badań zasadniczo potwierdziły uzyskane przez A. Kłoskowską obrazy stereotypów, pozwoliły także sformułować konstatację o dominacji kryteriów polityczno-ustrojowych w konstruowaniu obrazu Niemców, którzy w ówczesnym czasie występowali jako dwoista kategoria: polityczna i narodowa, a nie jako kategoria etniczna.

Na początku lat osiemdziesiątych do zagadnień zróżnicowania etnicznego i stosunków międzygrupowych powróciła Maria Szmeja. Kontynuowała wątki poznawcze wielkich poprzedników, Stanisława Ossowskiego, Stefana Nowakowskiego, Kazimierza Żygulskiego w paradygmacie integracyjnym, analizowała problematykę współżycia i stosunków międzygrupowych w społeczności lokalnej dwóch grup: Ślązaków i przesiedleńców z Kresów Wschodnich RP (Szmeja 1997). Podstawowe różnice między obiema społecznościami uwidoczniły się w sferze symbolicznej (gwara, uznawane normy i wartości, styl życia, aspiracje życiowe i plany na przyszłość). Jakkolwiek nie występował między nimi otwarty antagonizm, to jednak widoczny był brak harmonijnego współżycia. Utrzymywanie się w grupie śląskiej poczucia niesprawiedliwości i krzywdy silniej wyrażanych niż wśród ludności napływowej skłoniło autorkę do postawienia diagnozy „o widocznym stanie zbiorowej frustracji”.

\section{NOWA SYTUACJA USTROJOWA - NOWE WYZWANIA DLA SOCJOLOGII STOSUNKÓW ETNICZNYCH}

Zmiana społeczna rozpoczynająca się na przełomie lat osiemdziesiątych i dziewięćdziesiątych w Polsce wprowadziła kwestię mniejszości niemieckiej, jej istoty, miejsca i znaczenia dla stosunków etnicznych w regionie śląskim. Relacje między polską, śląską i niemiecką 
tożsamością wyznaczyły nurt analityczny dla zrozumienia owego społecznego fenomenu. Ślązacy zostali zdefiniowani, jako „społeczność etniczna”, zarzucono posługiwanie się terminami „grupy o odmiennych rodowodach regionalnych”, „grupy regionalno-kulturowe” na rzecz eksponowania cechy „etniczności” (Berlińska, Sołdra-Gwiżdż 1997). Ślązacy, w świetle wyników badań, stanowili izolującą się grupę w społeczeństwie polskim, dystansującą się od spraw narodowych, dla której Niemiecka Republika Federalna stanowiła kraj odniesienia, a socjalizm był utożsamiamy z „polskością i polskim porządkiem”. Odczucia niechęci i izolacjonizmu wobec narodu i państwa wzmacniały indywidualne krzywdy doznane po wojnie od władzy radzieckiej i ludności napływowej, o których żywa pamięć wpływała na dystanse społeczne w lokalnych społecznościach. Niski poziom życia w PRL oraz kryzys gospodarczy wzmacniały tendencje migracyjne i obraz Śląska jako ziemi skolonizowanej przez przybyszów, którzy nie umieli sprostać wyzwaniom (Berlińska 1990). Dwukrotnie przeprowadzone badania ankietowe wykazały, że ,alienacja polityczna Ślązaków jest głębsza i sprzęgnięta z wyobcowaniem kulturowym ze społeczeństwa polskiego" (Berlińska, Jonderko i Moj 1993). W konsekwencji Danuta Berlińska uznała Ślązaków za społeczną bazę mniejszości niemieckiej, którą określiła jako grupę „,W poszukiwaniu swojej tożsamości”(Berlińska 1999). Uznała, że antagonistyczny charakter stosunków międzygrupowych i utajone konflikty na tle etnicznym, próba akulturacji za pomocą ideologii komunistycznej, upadek systemu komunistycznego i procesy zjednoczenia Niemiec wywołały ponowny kryzys tożsamości w grupie śląskiej i skłonność do redefinicji tożsamości oraz kulturowego uniwersum w kierunku uwidocznienia związków z Niemcami.

Wyniki przeprowadzonych przeze mnie badań empirycznych wskazały na podobne procesy zachodzące wśród młodego pokolenia. Młodzież napływowa wyrażała tożsamość narodową i nie przejmowała dziedzictwa kulturowego grupy śląskiej. Śląska młodzież miała kłopoty z odróżnieniem tożsamości narodowej od poczucia więzi z grupą regionalną, określając swą narodowość relatywistycznie i atrybutywnie (przewaga tożsamości regionalnej nad narodową), której coraz częściej towarzyszyło akcentowanie niemieckich wpływów kulturowych bądź wyrażanie niemieckiej tożsamości narodowej. Instytucje społeczne (szkoła, instytucje kultury) wpływały na kształtowanie więzi regionalnych w niepełnym zakresie w stosunku do celów, które im przypisano. Dominujące znaczenie miał socjalizujący wpływ domu rodzinnego, który w największym stopniu kreował postawy emocjonalne i relacje etniczne (Więzi spoleczne... 1993; Sołdra Gwiżdż 1997). Rozszerzeniem i kontynuacją owych socjologicznych eksploracji były studia nad relacjami międzygrupowymi na Śląsku Opolskim, prowadzone pod kierunkiem Krzysztofa Frysztackiego w ramach projektu badawczego finansowanego przez Komitet Badań Naukowych ${ }^{3}$. Generalna konkluzja wzmacniana przez szczegółowe analizy: bagażu historycznego zawartego w indywidualnych doświadczeniach, prasy regionalnej, instytucji społecznych (szkoła, kościół, instytucje kultury, prasa lokalna), stereotypów, wzorów życia gospodarowania i świętowania, dynamiki tożsamości etnicznych i narodowych brzmiała następująco: „Można stwierdzić, że po drugiej wojnie światowej stosunki międzygrupowe

Projekt badawczy 1HO 1F 08908 pt. „Dynamika stosunków międzygrupowych na Śląsku Opolskim. Regionalna integracja czy izolacjonizmy?" finansowany przez Komitet Badań Naukowych, kierownik: Krzysztof Frysztacki. 
w kolejnych pokoleniach ewoluowały od otwartego antagonizmu, przez utajony konflikt i wymuszoną kooperację i izolacjonizmy do kooperacji i integracji funkcjonalnej” (Berlińska 1998: 70-74; Linek 1998; Jonderko 1998; Ruszczewska 1998; Sołdra-Gwiżdż 1998; Jonderko 1998; Ruszczewska 1998; Śmiełowska 1998).

Nieco inny obraz przemocy kulturowej w społecznościach lokalnych przyniosły, prowadzone przeze mnie badania w projekcie kierowanym przez Janusza Muchę ${ }^{4}$. Paradoks opolski polegał na tym, że o ile w skali Opolszczyzny dominowała grupa napływowa, to w wielu lokalnych społecznościach grupę dominującą stanowiła grupa śląska i nie chodzi tu o liczebność, bowiem tej w tym okresie nie sposób było ustalić, ale o dominujące wzory kulturowe, które wyznaczała. W tych społecznościach problem polskiej dominacji był, w moim przekonaniu, raczej pozorny (Sołdra-Gwiżdż 1999). Wprowadzenie kontrolowanej zmiany instytucjonalnej - reformy edukacji umożliwiającej wprowadzenie do szkół języka niemieckiego jako języka ojczystego, zakładanie klas dwujęzycznych i szkół mniejszościowych, czyli rozwój „etnicznej edukacji”, należy uznać za szczególny „impakt kulturowy”. Ujawniły się silne konflikty i napięcia społeczne związane z odczuciami dyskryminacji etnicznej tym razem wśród polskich mieszkańców lokalnych społeczności, które poczuły się zagrożone zmianami obwodów szkolnych i masowym wprowadzaniem do szkół języka niemieckiego jako języka ojczystego, nawet wbrew woli rodziców (Sołdra-Gwiżdż 2001; Sołdra-Gwiżdż 2003).

Ostatni projekt badawczy, który został zrealizowany w instytucie w latach 2010-2011, odnosił się do kształtowania relacji międzygrupowych społeczności przesiedleńców z Kresów Wschodnich II Rzeczypospolitej, która znalazła się w regionie opolskim w wyniku przymusowych migracji. Wyniki badań podtrzymały wcześniej postawioną tezę o ciągle trwającym procesie międzygrupowej integracji. Z pewną ostrożnością można jednak stwierdzić, iż wzajemne relacje nadal podlegają procesom zmiany społecznej, szczególnie w najmłodszych pokoleniach, kształtując się ewolucyjnie od wzajemnej wrogości, której podstawą były przynależności etniczne i narodowe w najstarszym pokoleniu przesiedleńców, do powoli kształtującej się tożsamości europejskiej opartej na uniwersalnych wartościach (Sadło 2011: 145-167).

\section{PODSUMOWANIE}

Socjologiczny dyskurs o badaniach nad stosunkami etnicznymi i narodowymi w Instytucie Śląskim był kilkukrotnie przedmiotem analiz i ocen. Przywołam jedną z opinii wyrażoną kilka lat temu przez Władysława Kwaśniewicza, który jednoznacznie stwierdził, iż zespół socjologów instytutu, zmieniający swój skład osobowy na przestrzeni dziejów, wykazywał się dużą dynamiką, potrafił skupiać kompetentnych badaczy, a jego wkład w badania nad stosunkami etnicznymi i narodowymi na Górnym Śląsku był znaczący (Kwaśniewicz 1997). Osobiście przychylam się do tej oceny, podkreślając jednocześnie znaczenie poznawcze i dojrzałość intelektualną prowadzonych studiów. Całość wysiłków badawczych instytutu opolskiego i katowickiego przestawiłam w autorskiej monografii (Sołdra-Gwiżdż 2010). W ostatniej

\footnotetext{
4 Projekt badawczy nr 1 H01F 10209 pt. „Kultura dominująca jako kultura obca. Mniejszości kulturowe a grupa dominująca w Polsce", finansowany przez Komitet Badań Naukowych, kierownik Janusz Mucha.
} 
zespołowej publikacji wydanej w Instytucie Śląskim podkreśliłam znaczenie społecznych czynników rozwoju nauki: osób i czynników instytucjonalnych (Sołdra-Gwiżdż 2013: 97-105). Z przykrością muszę w podsumowaniu tych rozważań potwierdzić, iż nadszedł w instytucie czas bardzo niekorzystnych zmian dla socjologów. Rozproszony zespół, brak liderów oraz niepewność finansowa sprawiaja, że mimo długiego trwania instytutu (80 lat) i różnych trudnych okresów w jego działalności, w chwili obecnej socjologiczne inicjatywy badawcze uległy zahamowaniu, a ewentualne możliwości ich wznowienia rysują się bardzo niepewnie.

\section{BIBLIOGRAFIA}

Berlińska, Danuta. 1990. Ślazacy na Ślasku Opolskim w świetle badań socjologicznych, w: Janusz Kroszel (red. nauk.), V Sympozjum. Górny Ślask jako pomost pomiędzy Polakami a Niemcami. Materiaty strony polskiej na V Sympozjum, Opole: Instytut Śląski.

Berlińska, Danuta, Franciszek Jonderko i Brygida Moj. 1993. Stosunki etniczne i postawy polityczne mieszkańców Ślaska Opolskiego, maszynopis, Opole: Instytut Śląski.

Berlińska, Danuta. 1998. Narodowo-etniczne stosunki międzygrupowe na Ślasku Opolskim: ciagłość i zmiana, w: Krzysztof Frysztacki (red.), Polacy, Ślazacy, Niemcy. Studia nad stosunkami społeczno-kulturowymi na Ślasku Opolskim, Kraków: TAiWPN UNIVERSITAS, s. 33-74,

Berlińska, Danuta. 1999. Mniejszość niemiecka w poszukiwaniu tożsamości, Opole: Stowarzyszenie Instytut Śląski, PIN - Instytut Śląski.

Berlińska, Danuta i Teresa Sołdra-Gwiżdż. 1997. Ludność rodzima i mniejszość niemiecka w Polsce. Stan badań, w: Grzegorz Babiński, Janusz Mucha i Andrzej Sadowski (red.), „Pogranicze. Studia Społeczne” 6: Polskie badania nad mniejszościami kulturowymi. Wybrane zagadnienia.

Bystroń, Jan S. 1917. Rozwój problemu socjologicznego w nauce polskiej. Archiwum dla historii filozofii w Polsce, t. 1, Kraków.

Chałasiński, Józef. 1935. Antagonizm polsko-niemiecki w osadzie fabrycznej „,Kopalnia” na Górnym Ślasku, Warszawa: Dom Książki Polskiej.

Chałasiński, Józef. Trzydzieści lat socjologii polskiej 1918-1947, „Przegląd Socjologiczny” 1948: 10.

Golachowski, Stefan. 1947. Ślask przez pryzmat socjologii (sprawozdanie Komisji Socjograficznej Instytutu Śląskiego), Katowice: Instytut Śląski.

Grygierczyk, Maria, Stanisław Jałowiecki, Maria Paszkiewicz, Andrzej Pasierbiński i Janusz Woźniacki. 1975. Postawy patriotyczne młodzieży, maszynopis, Biblioteka PIN -Instytutu Śląskiego w Opolu, zbiory specjalne.

Jonderko, Franciszek. 1998. Stereotypy etniczne na Ślasku Opolskim. Czy generacyjna zmiana?, w: Krzysztof Frysztacki (red.), Polacy, Ślazacy, Niemcy. Studia nad stosunkami społeczno-kulturowymi na Ślasku Opolskim, Kraków: TAiWPN UNIVERSITAS, s. 149-170.

Kłoskowska, Antonina. 1960. Postawy i wyobrażenia etniczne wśród dzieci szkół opolskich. Wyobrażenia grup etnicznych jako przedmiot socjalizacji, w: Wyobrażenia i postawy 
etniczne wśród dzieci szkół opolskich, Opole, maszynopis, Biblioteka PIN - Instytutu Śląskiego, zbiory specjalne, sygnatura A 576.

Kłoskowska, Antonina. 1969. Z historii i socjologii kultury, Warszawa: PWN .

Kraśko, Nina. 1996. Instytucjonalizacja socjologii w Polsce 1920-1970, Warszawa: Wydawnictwo Naukowe PWN.

Kraśko, Nina. 2010. Instytucjonalizacja socjologii w Polsce 1970-2000, Warszawa: Wydawnictwo Uniwersytetu Warszawskiego.

Kwaśniewicz, Władysław. 1997. O wkładzie socjologów w badania Instytutu Ślqskiego. Fakty i refleksje, „Śląsk Opolski” 3: 32-33.

Kwaśniewski, Krzysztof. 1968. Adaptacja i integracja kulturowa ludności Ślaska po II wojnie światowe, Wrocław: PWN.

Linek, Bernard. 1998. Obraz mieszkańców Ślaska Opolskiego na łamach prasy regionalnej: tożsamość grupowa, relacje międzygrupowe, modele wspótistnienia, w: Krzysztof Frysztacki (red.), Polacy, Ślazacy, Niemcy. Studia nad stosunkami społeczno-kulturowymi na Ślasku Opolskim, Kraków, TAiWPN UNIVERSITAS, s. 75-117.

Nawrocki, Tomasz. 2006. Trwanie i zmiana lokalnej społeczności górniczej na Górnym Ślasku. Na przykładzie Murcek, Katowice: Wydawnictwo Uniwersytetu Śląskiego.

Nijakowski, Lech. 2006. Domeny symboliczne. Konflikty narodowe i etniczne $w$ wymiarze symbolicznym. Warszawa: Wydawnictwo Naukowe Scholar.

Nowakowski, Stefan. 1957. Adaptacja ludności na Ślasku Opolskim, Poznań: Instytut Zachodni.

Nowakowski, Stefan. 1967. Narodziny miasta, Warszawa: PWN

Nowakowski, Stefan. 1960. Przeobrażenia społeczne wsi opolskiej, Poznań: Instytut Zachodni. Obrębski, Józef. 1936. Problem etniczny Polesia, „Sprawy Narodowościowe” 10, 1/2: 1-21. Olszewska-Ładykowa, Anna i Kazimierz Żygulski. 1959. Matżeństwa mieszane na Ślasku Opolskim, „Przegląd Socjologiczny” XIII, 1: 89-105.

Olszewska, Anna. 1969. Wieś uprzemystowiona. Studium społeczności lokalnej w powiecie opolskim, Wrocław: Wydawnictwo Polskiej Akademii Nauk.

Ossowski, Stanisław. 1984. Zagadnienia więzi regionalnej i więzi narodowej na Ślasku Opolskim, w: O ojczyźnie i narodzie. Warszawa: PWN.

Pasierbiński, Andrzej. 1997. Elementy wyobrażeń i postaw etnicznych młodzieży szkół średnich, „Biuletyn Naukowy Zakładu Stosunków Międzynarodowych” 1.

Ruszczewska, Violetta. 1998. Wzory życia, gospodarowania i świętowania na Ślasku Opolskim, w: Krzysztof Frysztacki (red.), Polacy, Ślazacy, Niemcy. Studia nad stosunkami społeczno-kulturowymi na Ślasku Opolskim, Kraków, TAiWPN UNIVERSITAS, s. 171-195.

Rybicki, Paweł. 1938. O badaniu socjograficznym Ślaska. Katowice, Instytut Śląski.

Sadło, Paweł. 2011. W grupie i poza niq. Międzygrupowe relacje, w: Robert Rauziński i Teresa Sołdra-Gwiżdż (red.), Wokót ludzi i zdarzeń. Przesiedleńcy z dawnych Kresów Rzeczypospolitej w strukturze demograficznej i społecznej Ślaska Opolskiego w sześćdziesięcioleciu 1945-2005, Opole: PIN - Instytut Śląski, s. 145-167.

Senft, Stanisław. 1994. Meandry Instytutu Ślaskiego w latach 1939-1956, w: Krystian Heffner (red.), Instytut Ślaski 1934-1994, Opole, PIN - Instytut Śląski, s. 32-40. 
Sołdra-Gwiżdż, Teresa. 1997. Między rzeczywistościq lokalnq i regionalnq. Wybrane instytucje społeczne Ślaska Opolskiego, Opole. PIN - Instytut Śląski.

Sołdra-Gwiżdż, Teresa. 1998. Instytucje w procesach kształtowania stosunków grupowych w społecznościach lokalnych Ślaska Opolskiego, w: Krzysztof Frysztacki (red.), Polacy, Ślazacy, Niemcy. Studia nad stosunkami społeczno-kulturowymi na Ślasku Opolskim, Kraków: TAiWPN UNIVERSITAS, s. 119-147.

Sołdra-Gwiżdż, Teresa. 1999. Problem dominacji kulturowej w społecznościach lokalnych Ślaska Opolskiego, w: Janusz Mucha (red.), Kultura dominująca jako kultura obca. Mniejszości kulturowe a grupa dominujaca w Polsce, Warszawa: Oficyna Naukowa.

Sołdra-Gwiżdż, Teresa. 2001. Rozważania o edukacji mniejszości etnicznych, w: Michał Lis i Stanisław Senft (red.), Ślask Opolski - na styku kultur etniczno-narodowych i interesów państwowych, ,Śląsk Opolski” 2: 79-82.

Sołdra-Gwiżdż, Teresa. 2003. Edukacja etniczna w województwie opolskim, w: R. Rauziński (red.), Ludność Ślaska-procesy demograficzne i społeczne w okresie transformacji ustrojowej, Opole: Politechnika Opolska.

Sołdra-Gwiżdż, Teresa. 2010. Socjologia wobec Ślaska. Jedność czy wielość?, Opole: Stowarzyszenie Instytut Śląski, PIN - Instytut Śląski.

Sołdra-Gwiżdż, Teresa. 2013. Socjologia w Instytucie Ślaskim. Czy zamykajaca się karta?, w: Krzysztof Frysztacki (red.), Opolszczyzna. Instytut Ślaski. Socjologiczne warsztaty doktoranckie, Opole, Stowarzyszenie Instytut Śląski, PIN - Instytut Śląski, s. 97-104.

Sto lat socjologii polskiej. Od Supińskiego do Szczepańskiego, Jerzy Szacki (wybór i red.), Warszawa: Wydawnictwo Naukowe PWN, s. 11-113.

Szczepański, Jan. 1934. Recenzja pracy E. Szramka, „Przegląd Socjologiczny” 2: 163-164. Szczepański, Jan. 1935. Socjologiczne problemy Śląsk, „Zaranie Śląskie” 2: 94.

Szmeja, Maria. 1997. Starzy i nowi mieszkańcy Opolszczyzny, Opole: Stowarzyszenie Instytut Śląski, PIN - Instytut Śląski.

Szramek, Emil. 1934. Ślask jako problem socjologiczny. Próba analizy, Katowice: Instytut Śląski.

Śmiełowska, Maria. 1998. Tożsamości etniczne i identyfikacje narodowe wśród mieszkańców Ślaska Opolskiego, w: Krzysztof Frysztacki (red.), Polacy, Ślazacy, Niemcy. Studia nad stosunkami społeczno-kulturowymi na Ślasku Opolskim, Kraków: TAiWPN UNIVERSITAS, s. 197-238.

Świrski, Władysław. 1965. Nowa społeczność wsi Grzybowice, Opole: Instytut Śląski.

Więzi społeczne w regionie (Studium socjologiczne młodzieży Ślaska Opolskiego). 1993. Krzysztof Frysztacki i Teresa Sołdra-Gwiżdż (red.), Opole: PIN - Instytut Śląski.

Znaniecki, Florian. 1930/31. Studia nad antagonizmem do obcych, „Przegląd Socjologiczny" 1, 2-4: 158-209.

Znaniecki, Florian. 1990. Wspótczesne narody, Warszawa: PWN.

Żygulski, Kazimierz. 1959. Matżeństwa mieszane w Opolu $w$ latach 1945-1957, „Studia Śląskie" 2: 235-275.

Żygulski, Kazimierz. 1958. Przyczyny wyjazdu ludności rodzimej z województwa opolskiego na Zachód. Referat wygłoszony na konferencji naukowej Instytutu Ślaskiego w Opolu 
dnia 12 maja 1958 roku, maszynopis, zbiory specjalne, Biblioteka Instytutu Śląskiego w Opolu, sygnatura 765 III.

Żygulski, Kazimierz. 1960. Badania nad prestiżem zawodów na Opolszczyźnie, „Przegląd Socjologiczny" XIV/2: 105-109.

Żygulski, Kazimierz. 1964. Wybór i poważanie zawodów na Ślasku, Warszawa: Instytut Filozofii i Socjologii PAN.

\section{ETHNIC RELATIONS IN THE STUDIES OF SILESIAN INSTITUTE FROM THE PERSPECTIVE OF ITS EIGHTY YEARS OF EXISTENCE}

The article presents a sociological discourse about studies of ethnic and national relations which have been conducted at the Silesian Institute since the establishment of this institution in 1934. The main aim of the discourse is to show the significance of Silesia as an independent subject of study, a peculiar social laboratory, and a source of social factors in the development of science. Seeing as sociologists who discuss the state of research in the scope of ethnic and national problems in Polish sociology rarely reach for the accomplishments of the institute, I began my considerations with presenting classical studies of E. Szramek, J. Chałasiński, P. Rybicki, S. Ossowski and S. Nowakowski, showing the evolution of the problem areas and theoretical frameworks which lay at the foundation of different projects taken up by the Institute. The historical perspective accepted in the article made it possible for me to present the significance of processes of social change for the conceptualization of the ethnic problem area, which differs greatly from that in the time of socialism, transformations in identity, redefinition of it and the cultural universum of Silesians in the direction of demonstrating their relations with Germans, while - among the younger generation - a European identity based on universal values, which is slowly taking shape.

Key words: ethnic relations, Silesian Institute, transformations in the national and ethnic identity, institutional factors in the development of science 